\title{
Mycoplasma-like Organisms from Plants with 'Yellows' Diseases Lack a Spiroplasma-specific Antigen
}

\author{
By R. TOW NSEND \\ John Innes Institute, Colney Lane, Norwich NR4 7UH, U.K.
}

(Received 4 November 1982)

\begin{abstract}
An antigen which is specific to Spiroplasma and was unaffected by changes in cell morphology was used to demonstrate the presence of spiroplasmas in diseased plant material. The same antigen could not be detected in plants infected with eight different 'yellows' diseases with which non-cultivable mycoplasma-like organisms were associated.
\end{abstract}

\section{INTRODUCTION}

The characteristic feature of spiroplasmas which distinguishes them from all other cell wallfree prokaryotes is their helical morphology as seen in culture. However, they frequently lose this helical shape in the tissues of vector insects (Davis, 1979; Granados \& Meehan, 1975; Townsend et al., 1976; Whitcomb \& Williamson, 1975) or infected plants (Davis et al., 1981; Granados, 1969; Igwegbe \& Calavan, 1970; Markham \& Townsend, 1979; Townsend et al., 1977). Instead they assume an apparently ovoid pleomorphic form which renders them indistinguishable from the mycoplasma-like organisms (MLOs) which are consistently associated with one hundred or so other 'yellows' plant diseases. Since these organisms have proved refractory to cultivation in cell-free media, it would be unwise to conclude that most yellows diseases are associated with mycoplasmas rather than spiroplasmas simply because profiles indicative of helices are not apparent in sections of diseased tissue. A more reliable diagnostic criterion is required which is stable and unique to spiroplasmas but independent of cell morphology and which can be detected in infected plants, without recourse to complex purification procedures or culture in cell-free media.

Spiroplasmas contain long flexuous fibrils which are composed of a single protein of mol. wt 55000 (Townsend et al., 1980a). Circumstantial evidence suggests that these form part of the mechanism which maintains cell shape and generates motility, although they also occur in a stable non-helical variant of Spiroplasma citri, ASP-1 (Townsend et al., $1980 \mathrm{~b}$; Townsend et al., 1977). Townsend \& Archer (1983) have recently shown that this fibril protein is a Spiroplasmaspecific antigen. Antibodies directed against SDS-denatured fibrils purified from the honeybee spiroplasma (BC3) recognized $55000 \mathrm{~mol}$. wt proteins in all the spiroplasmas examined by these authors, including ASP-1, but failed to react with any components in several Mycoplasma spp. or Acholeplasma spp. which were tested.

In the current study the effects of changes in spiroplasma morphology on the occurrence of fibril protein have been investigated. A method is described for the detection of specific antigens in diseased tissue and the results of screening for fibril protein antigen in plants infected with several different yellows diseases are reported.

\section{METHODS}

Spiroplasmas. The SP-A strain of S. citri (NCPPB 2526) (Markham et al., 1974) and non-helical variants ASP-3 and ASP-12 were isolated in this laboratory. Honeybee spiroplasma BC3 was supplied by T. B. Clark, Bioenvironmental Bee Laboratory, Plant Protection Institute, U.S. Department of Agriculture, Beltsville, Maryland, U.S.A. 
Cultures. Spiroplasmas were grown in SMC medium (100 ml) (Markham et al., 1974) containing 10\% (v/v) foetal calf serum and incubated at $32^{\circ} \mathrm{C}$. Cells were harvested after $36 \mathrm{~h}$ or $120 \mathrm{~h}$ by centrifugation $(15000 \mathrm{~g}$, $15 \mathrm{~min}, 4^{\circ} \mathrm{C}$ ). Spiroplasmas were isolated from plants as described previously (Markham et al., 1974) except that duplicate $0.1 \mathrm{ml}$ samples of diluted filtrate were mixed with SMC containing $0.7 \%$ agar at $48{ }^{\circ} \mathrm{C}$ and rapidly poured over the surface of $5 \mathrm{~cm}$ plates of SMC solidified with $1 \%$ agar. Resulting colonies were counted after $10-$ $14 \mathrm{~d}$ incubation at $32^{\circ} \mathrm{C}$. This pour-plate method promoted better and more consistent growth of $S$. citri than direct plating (unpublished observation).

Infected material. Symptom-bearing tissue from Madagascar periwinkles (Catharanthus roseus) infected with five symptomatologically distinct yellows diseases originally occurring in apple (Malus domestica), cabbage (Brassica oleracea), clover (Trifolium repens), hydrangea (Hydrangea macrophylla) and primula (Primula sp.), as well as typical clover phyllody and European aster yellows, also in periwinkle (de Leeuw, 1977), was supplied by G. T. N. de Leeuw. The 'monstrose' variant of Opuntia tuna cactus (Casper et al., 1970) and periwinkles infected with S. citri (SP-A) and corn stunt spiroplasma (Markham et al., 1977) have been maintained for several years by grafting. Dalbulus maidis leafhoppers were used to transmit corn stunt spiroplasma (E275 Rio Grande ATCC 27954) to maize (Zea mays).

Electron microscopy. Small pieces of symptom-bearing shoot tissue were processed and examined as described previously (Markham et al., 1974).

Sample preparation. Samples $(100 \mathrm{mg})$ of symptom-bearing or healthy shoot and flower tissue from periwinkles, or pieces of maize leaf showing symptoms of severe chlorotic striping typical of corn stunt disease, were homogenized in $10 \mathrm{ml} 50-\mathrm{mM}$-Tris (which was adjusted to $\mathrm{pH} 7.8$ with $5 \mathrm{M}-\mathrm{HCl}$ and contained $60 \mathrm{mM}-\mathrm{KCl}$ and $6 \mathrm{mM}$-2-mercaptoethanol). Homogenates were clarified by centrifugation $\left(1000 \mathrm{~g}, 5 \mathrm{~min}, 20^{\circ} \mathrm{C}\right)$ and Triton X-100 was added to a final concentration of $1 \%(\mathrm{w} / \mathrm{v})$. The solution was centrifuged $\left(70000 \mathrm{~g}, 30 \mathrm{~min}, 20^{\circ} \mathrm{C}\right)$ to bring down detergent-insoluble material, which includes spiroplasma fibrils (Townsend et al., 1980a). The resulting pellets were extracted with detergent, centrifuged and finally taken up in SDS sample buffer $(100 \mu \mathrm{l})(\mathrm{Laemmli}$, 1970) and heated at $98{ }^{\circ} \mathrm{C}$ for $5 \mathrm{~min}$.

Harvested cells were washed in $25 \mathrm{ml} 10 \mathrm{~mm}$-Tris/ $\mathrm{HCl} \mathrm{pH} 7.8$ (containing $5 \%$, w/v, sorbitol to prevent cell lysis) and then centrifuged $\left(15000 \mathrm{~g}, 15 \mathrm{~min}, 4^{\circ} \mathrm{C}\right)$. The pelleted cells were then resuspended in $1 \mathrm{ml}$ water with the aid of a sonic probe (Dawe type 7530 A, London, U.K.) and then solubilized in an equal volume of $2 \times$ SDS sample buffer. Protein determinations were made by a modified Coomassie brilliant blue binding assay (Zaman $\&$ Verwilghen, 1979).

Fibril protein was prepared from BC3 cells as described previously (Townsend et al., 1980a) and dilutions containing between $500 \mu \mathrm{g} \mathrm{ml}^{-1}$ and $5 \mathrm{ng} \mathrm{ml}^{-1}$ were made in SDS sample buffer.

Electrophoretic separation, blotting and immunodetection of antigens. Samples of SDS-solubilized plant material (equivalent to $40 \mathrm{mg}$ fresh tissue) or cell extracts (equivalent to $5 \mu \mathrm{g}$ total cell protein) or samples containing between $5 \mu \mathrm{g}$ and $0.05 \mathrm{ng}$ purified fibril protein were electrophoresed in SDS-polyacrylamide linear gradient gels $(7 \cdot 5-25 \%, w / v$, acrylamide). Separated proteins were then blotted on to nitrocellulose filters by diffusion in the presence of $4 \mathrm{M}$-urea (Bowen et al., 1980). Antigens bound to the filters were detected by a double-antibody probe technique (Towbin et al., 1979). Briefly, filters were probed first with antiserum raised against the SDS-denatured BC3 fibril protein (Townsend \& Archer, 1983) (1:1000) and secondly with goat antiserum raised against rabbit IgG and conjugated to horse-radish peroxidase (Miles, Slough, U.K.) $(1: 2000)$. Bound conjugate was developed with the substrate 4-chloro-1-naphthol which gives rise to a blue coloured insoluble product (Hawkes et al., 1982). Molecular weights were calculated with reference to standards of known molecular weight blotted to nitrocellulose and stained with Coomassie brilliant blue. Full details of this technique have been published recently (Townsend \& Archer, 1983).

\section{RESULTS}

\section{Morphology of spiroplasmas in culture}

Cultures of S. citri (SP-A) contained numerous helical motile cells at the completion of the exponential phase of growth $(36 \mathrm{~h}$ ). If incubation was continued all the morphological changes associated with ageing spiroplasma cultures occurred (Townsend et al., 1980 b). After $120 \mathrm{~h}$, all the cells had lost their helical shape and the filaments had begun to constrict into chains of small spherical bodies. These changes were accompanied by a decline in viability from more than $10^{9}$ c.f.u. $\mathrm{ml}^{-1}$ at the end of exponential growth to less than $10^{4}$ c.f.u. $\mathrm{ml}^{-1}$. Isolates ASP-3 and ASP12 grew as short branching, non-helical filaments similar in appearance to cells of strain ASP-1 (Townsend et al., 1980 b; Townsend et al., 1977). 


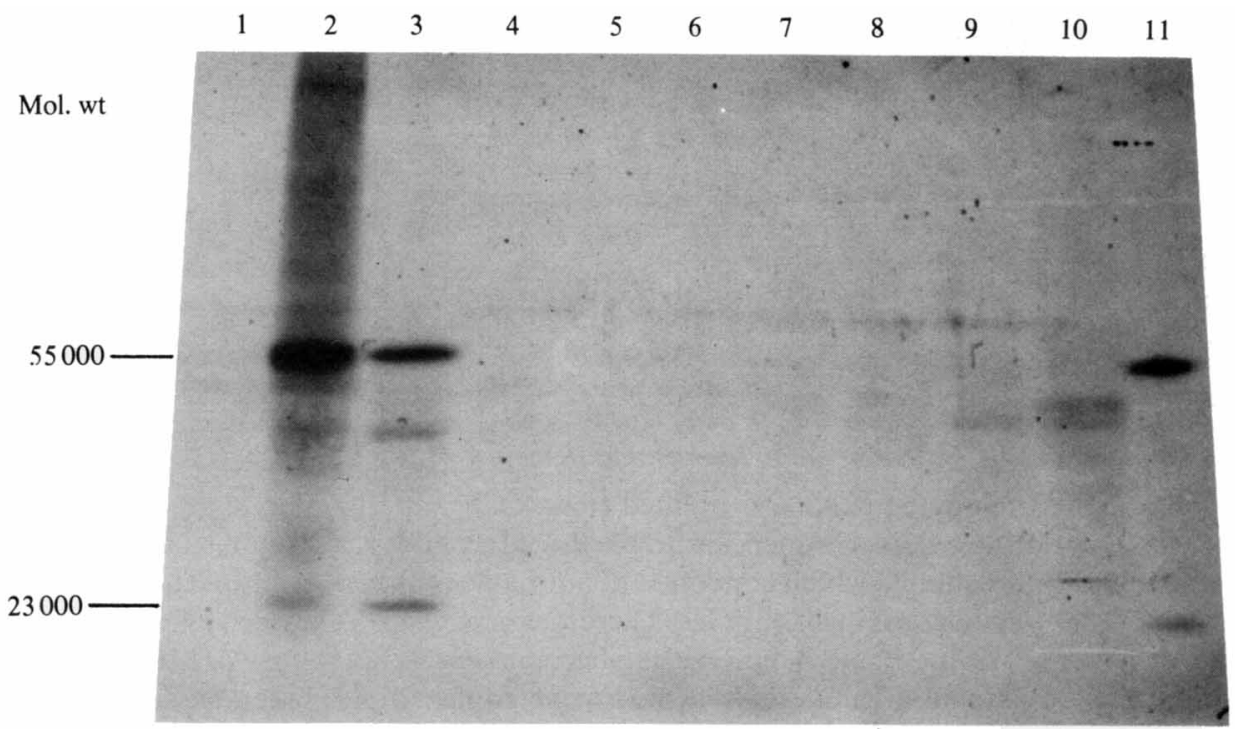

Fig. 1. Blot showing the occurrence of antigens in plant extracts and BC 3 spiroplasma cells. Gels were loaded with detergent-insoluble extracts equivalent to $40 \mathrm{mg}$ fresh tissue from (track 1) healthy periwinkle and (tracks 2-10) periwinkles infected with 2, S. citri; 3, corn stunt; 4, clover phyllody; 5 , clover disease; 6 , cabbage disease ; 7, European aster yellows; 8 , primula disease; 9 , hydrangea disease and 10 , apple disease. Track 11 contains $125 \mathrm{ng} \mathrm{BC} 3$ cell protein. Smearing in track 2 is probably due to incomplete dissociation of the Triton X-100-protein complexes (Townsend et al., 1980a).

\section{Electron microscopy of infected plants}

Representative samples from each of the eight yellows diseases contained numerous membrane-bound structures resembling mycoplasmas within the phloem sieve elements. Most of these structures were apparently spherical or ovoid but filamentous forms were present in some sections, particularly those from periwinkles infected with cabbage and hydrangea diseases. Sometimes these filaments terminated in chains of spherical bodies resembling structures which occurred in aged spiroplasma cultures (Townsend et al., 1980 b). The phloem sieve elements of the monstrose cactus were packed with ovoid MLOs, some of which were nearly $2 \mu \mathrm{m}$ in diameter, but no filaments or helical cells were detected.

\section{Detection of fibril antigen in cultured spiroplasmas}

Less than $0.5 \mathrm{ng}$ purified fibril protein produced a detectable band at a position corresponding to a mol. wt of 55000 on probed and developed blots. Blots of total SP-A proteins ( $36 \mathrm{~h}$ ) showed the presence of a major antigen of the same molecular weight and another of mol. wt 23000 . The same proteins were present on blots derived from non-helical strains ASP-3 and ASP-12 and SPA after $120 \mathrm{~h}$ incubation.

\section{Detection of fibril antigen in diseased plants}

Duplicate samples from two periwinkles graft-infected 4 weeks previously with $S$. citri contained significant amounts of $55000 \mathrm{~mol}$. wt antigen (Fig. 1, track 2). Several minor bands were also visible including one of mol. wt 23000 . Some of these were also detected in extracts from healthy plants (Fig. 1, track 1) and showed non-specific binding of rabbit globulins on blots incubated with pre-immune serum. No antigens of mol. wt 55000 or 23000 were detected in healthy plants. Extracts from periwinkles (Fig. 1, track 3) and two maize plants infected with corn stunt spiroplasmas also contained $55000 \mathrm{~mol}$. wt antigen. No $55000 \mathrm{~mol}$. wt antigen was detected in any samples of symptom-bearing tissue (two samples per plant) from pairs of periwinkles infected with any of the other diseases or from two monstrose cacti. 
Table 1. Isolation of colony-forming units from a periwinkle following graft infection with $S$. citri Plant material was maintained at a mean temperature of $30 \pm 5{ }^{\circ} \mathrm{C}$.

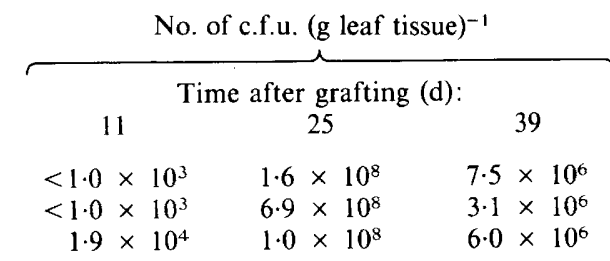

\section{Isolation of spiroplasmas and detection of fibril antigen}

Table 1 shows the numbers of c.f.u. isolated from a single periwinkle plant at various time intervals after grafting on three branches with $S$. citri. After $11 \mathrm{~d}, 55000 \mathrm{~mol}$. wt antigen was just detectable in the only sample which contained quantifiable numbers of c.f.u. Thereafter, 55000 mol. wt material was detected in all samples. There was a marked decrease in c.f.u. titre between day 25 and day 39, by which time symptoms had become severe, but there was little difference in the amount of 55000 mol. wt material that was detected in samples taken on days 25 and 39 .

\section{DISCUSSION}

The unstable morphology of spiroplasmas and the variety of filamentous and pleomorphic forms assumed by non-cultivable MLOs in plants clearly demonstrates the problems associated with the use of morphology as a diagnostic or taxonomic criterion. However, fibril protein was found to be a stable antigenic marker for Spiroplasma, which was not affected by changes in cell morphology.

Viable counting suggested that concentrations of spiroplasmas as low as $2 \times 10^{4}$ cells per $g$ of infected tissue could be detected. However, tissue containing less than $6 \times 10^{6}$ spiroplasmas per $\mathrm{g}$ is unlikely to yield sufficient fibril protein to be resolved by this technique. This disparity probably reflects the loss of viable organisms during the extraction procedure. Changes in the morphology or impaired motility have been shown to result in losses of up to $99 \%$ of viable spiroplasmas during passage through $0.22 \mu \mathrm{m}$ pore diameter membrane filters (Saglio, 1979).

Furthermore, since the antigenic character and concentration of fibril protein were not significantly affected by loss of cell viability, it is possible that many of the pleomorphic mycoplasma-like structures present in the phloem sieve elements of plants showing severe $S$. citri symptoms may no longer be viable.

The antiserum also reacted with proteins of $23000 \mathrm{~mol}$. wt from cultured cells and spiroplasma-infected plants. These proteins are thought to be related to spiralin which is the major $S$. citri membrane antigen (Archer \& Townsend, 1981).

It has been reported that a spiroplasma serologically related to $S$. citri was isolated from a monstrose variant of $O$. tuna (Kondo et al., 1976). The cacti used in the present study showed the same symptoms but did not contain detectable quantities of fibril protein. Although repeated attempts to culture spiroplasmas from these plants have been unsuccessful (unpublished results) it is possible that they are dually infected with a non-cultivable MLO and $S$. citri which is present in very low concentrations. A disease complex of $S$. citri and an MLO associated with virescence (greening of the flowers) of $C$. roseus has recently been described (Oldfield, 1982). Dually infected plants showed typical virescence, symptoms of $S$. citri infection were markedly suppressed and the numbers of spiroplasmas present were significantly lower than in appropriate controls (Kloepper et al., 1982).

The sensitivity with which fibril protein could be detected by the method described here is comparable to that achieved using enzyme-linked immunosorbent assay (ELISA) of nondenatured spiroplasma antigens (Archer \& Best, 1980). Unlike ELISA, this method is not quantitative and is unsuitable for multiple assays. But, it can provide qualitative information on the occurrence and relative concentrations of a number of different antigens in a complex 
mixture depending only on a difference in molecular weight. No fibril protein was detected in plants infected with any of the other yellows diseases although they contained numerous MLOs. It has been estimated that the phloem sap of a plant infected with a typical yellows disease contains as many as $10^{13}$ MLOs $\mathrm{ml}^{-1}$ (Daniels et al., 1982). This represents about $10^{10} \mathrm{MLOs}$ per $\mathrm{g}$ of $C$. roseus tissue which is well within the detection limits of the method described here, even allowing for antigenic diversity among proteins from different spiroplasmas (Townsend \& Archer, 1983). Therefore it is very unlikely that the non-cultivable MLOs associated with the majority of yellows diseases are related to Spiroplasma.

I wish to thank Dr G. T. N. de Leeuw, Phytopathological Laboratory 'Willie Commelin Scholten', Baarn, Netherlands and Dr P. G. Markham, John Innes Institute for providing the yellows-diseased material used in the study, Miss S. J. Curson for technical assistance and Miss K. A. Plaskitt for electron microscopy. This study was performed under licence No. PHF $49 / 41$ issued by the Ministry of Agriculture, Fisheries and Food under the Destructive Pests and Diseases of Plants Order 1965.

\section{REFERENCES}

ARCher, D. B. \& BeST, J. (1980). Serological relatedness of spiroplasmas estimated by enzyme-linked immunosorbent assay and crossed-immunoelectrophoresis. Journal of General Microbiologv 119 , 413-422.

ARCHER, D. B. \& TownSEND, R. (1981). Immunoelectrophoretic separation of spiroplasma antigens. Journal of General Microbiology 123, 61-68.

Bowen, B., Steinberg, J., Laemmli, U. K. \& WeintrauB, H. (1980). The detection of DNAbinding proteins by protein blotting. Nucleic Acids Research 8, 1-20.

Casper, R., Lesemann, D. \& Bartels, R. (1970). Mycoplasma-like bodies and viruses in Opuntia tuna with witches' broom disease. Plant Disease Reporter 54, 851-853.

Daniels, M. J., Archer, D. B. \& Stemmer, W. P. C. (1982). Interaction of wall-free prokaryotes with plants. In Bacteria and Plants. Society for Applied Bacteriology Symposium Series No. 10, pp. 85-99. Edited by M. E. Rhodes-Roberts \& F. A. Skinner. London: Academic Press.

DAvIS, R. E. (1979). Spiroplasmas: newly recognised arthropod borne pathogens. In Leafhopper Vectors and Plant Disease Agents, pp. 451-484. Edited by K. Maramorosch \& K. F. Harris. New York: Academic Press.

Davis, R. E., Chen, T-A. \& Worley, J. F. (1981) Corn stunt spiroplasma. In Virus and Virus-like Diseases of Maize in the United States; Southern Cooperatice Sales Bulletin 247 June 1981, pp. 40-50. Edited by D. T. Gordon \& J. K. Knoke. Wooster, Ohio: Ohio Agricultural Research and Development Center.

Granados, R. R. (1969). Electron microscopy of plants and insect vectors infected with corn stunt disease agent. Contributions of the Boyce Thompson Institute 24, 173-187.

Granados, R. R. \& Meehan, D. J. (1975). Pathogenicity of the corn stunt agent to an insect vector Dalbulus elimatus. Journal of Invertebrate Pathology 26, 313-320

HaWkes, R., NidAy, E. \& GoRdon, J. (1982). A dotimmunobinding assay for monoclonal and other antibodies. Analytical Biochemistry 119, 142-147.

Igwegbe, E. C. K. \& Calavan, E. C. (1970).
Occurrence of mycoplasma-like bodies in phloem of stubborn-infected citrus seedlings. Phytopathology 60, 1525-1526.

Kloepper, J. W., Garrott, D. G. \& Oldfield, G. N. (1982). Quantification of plant pathogenic spiroplasmas from infected plants. Phytopathology 72, 577581 .

Kondo, F., McIntosh, A. H., Padhi, S. B. \& MARAMOROSCH, K. (1976). A spiroplasma isolated from the ornamental cactus Opuntia tuna monstrosa. Proceedings of the Society for General Microbiology 3, 154.

LAEMMLI, U. K. (1970). Cleavage of structural proteins during the assembly of the head of bacteriophage T4. Nature, London 277, 680-685.

DE LEEUW, G. T. N. (1977). Mycoplasmas in planten. Natur en Technik 45, 74-89.

Markham, P. G. \& Townsend, R. (1979). Experimental vectors of spiroplasmas. In Leafhopper Vectors and Plant Disease Agents, pp. 415-443. Edited by K. Maramorosch \& K. F. Harris. New York: Academic Press.

Markham, P. G., Townsend, R., Bar-Joseph, M., Daniels, M. J., Plaskitt, A. \& Meddins, B. M. (1974). Spiroplasmas are the causal agents of citrus little-leaf disease. Annals of Applied Biology 78, 4957.

Markham, P. G., Townsend, R., Plaskitt, K. A. \& SAGL10, P. (1977). Transmission of corn stunt to dicotyledonous plants. Plant Disease Reporter 61, 342-345.

OLDFIELD, G. N. (1982). A virescence agent transmitted by Circulifer tenellus (Baker); aspects of its plant host range and association with Spiroplasma citri. Retiews of Infectious Diseases, Vol. 4, Supplement, May-June 1982, p. S248.

SAGLIO, P. (1979). Motility and improvement in selective isolation of spiroplasmas. Plant Disease Reporter 63, 293-296.

Towbin, H., Staehelin, T. \& Gordon, J. (1979). Electrophoretic transfer of proteins from polyacrylamide gels to nitrocellulose sheets: procedure and some applications. Proceedings of the National Academy of Sciences of the United States of America 76, $4350-4354$

Townsend, R. \& ARCher, D. B. (1983). Fibril protein 
is an antigen specific to Spiroplasma. Journal of General Microbiology 129, 199-206.

Townsend, R., ARcher, D. B. \& Plaskitt, K. A. $(1980 a)$. Purification and preliminary characterisation of spiroplasma fibrils. Journal of Bacteriology 142, 694-700.

Townsend, R., Burgess, J. \& Plaskitt, K. A. $(1980 \mathrm{~b})$. Morphology and ultrastructure of helical and non-helical strains of Spiroplasma citri. Journal of Bacteriology 142, 973-981.

Townsend, R., Markham, P. G. \& Plaskitt, K. A. (1976). Multiplication and morphology of Spiroplasma citri in the leafhopper Euscelis plebejus. Annals of Applied Biology 87, 307-313.
Townsend, R., Markham, P. G., Plaskitt, K. A. \& DANIELS, M. J. (1977). Isolation and characterization of a non-helical strain of Spiroplasma citri. Journal of General Microbiology 100, 15-21.

Whitcomb, R. F. \& Williamson, D. L. (1975). Helical wall-free prokaryotes in insects: multiplication and pathogenicity. Annals of the New York Academy of Sciences 266, 260-275.

ZAMAN, Z. \& VERWILGHEN, R. L. (1979). Quantitation of proteins solubilised in sodium dodecyl sulphatemercaptoethanol-Tris electrophoresis buffer. Analytical Biochemistry 100, 6469. 